\title{
THE RESIDUAL EFFECT OF PRIOR DROP JUMPS ON EMG PARAMETERS OF THIGH MUSCLES DURING MODERATE AND HEAVY CYCLING
}

\author{
Neringa Baranauskienė, Loreta Stasiulè, Sandra Raubaitė, Arvydas Stasiulis \\ Lithuanian Academy of Physical Education, Kaunas, Lithuania
}

\begin{abstract}
Research background and hypothesis. Prior eccentric or eccentric-concentric exercise induces long lasting muscle fatigue and delayed onset muscle soreness (DOMS). Moreover, the surface electromyograme sEMG amplitude increases under fatigue conditions. We suppose that prior eccentric - concentric exercise, inducing DOMS, increases EMG amplitude of thigh muscles during constant cycling exercises.

Research aim of the study was to assess the residual effect of 100 prior drop jumps (PDJ) on the sEMG of $m$. vastus lateralis and $m$. vastus medialis during moderate and heavy intensity cycling exercises.

Research methods. On four different days 10 female students performed one increasing and three (control, $45 \mathrm{~min}$ and $24 \mathrm{~h}$ after 100 drop jumps) moderate and heavy cycling (Ergoline-800, Germany) exercises. The cadence of cycling was $70 \mathrm{rpm}$. The sEMG of right thigh $m$. vastus lateralis and $m$. vastus medialis were continuously recorded during moderate and heavy cycling exercise. Creatine kinasis activity was measured and DOMS was rated $24 \mathrm{~h}$ after PDJ.

Research results. After $24 \mathrm{~h}$ the subjects felt moderate DOMS (5.0 (2.79)) according to 10 point scale. The sEMG root mean square amplitude of $m$. vastus lateralis significantly increased $24 \mathrm{~h}$ after PDJ during moderate, but unaltered during heavy cycling exercise under fatigue conditions ( $45 \mathrm{~min}$ and $24 \mathrm{~h}$ after PDJ).

Discussion and conclusion. Prior drop jumps seem to have significant residual (within $24 \mathrm{~h}$ of recovery) effect on EMG of thigh muscles during moderate cycling exercise in female students.
\end{abstract}

Keywords: delayed onset muscle soreness, constant load, EMG root mean square.

\section{INTRODUCTION}

$\mathrm{R}$ epeated eccentric muscle actions, during which the muscle lengthens during action, are known to induce delayed onset muscle soreness (DOMS), which is first felt $6-10$ hours post exercise and peaks between 24 and $48 \mathrm{~h}$ post exercise (Gleeson et al., 1995). Associates with eccentric exercise induced DOMS are evidence of muscle fibres disarrangement (Hortobagy et. al., 1996; Stupka et al., 2001; Laanksonen et al., 2006; Malm, Yu, 2012), increased serum creatine kinase (CK) activity (Gleeson et al., 1995; Stupka et al., 2000; Chen et al., 2010; Skurvydas et al., 2010), decreased muscle force production (Chen et al., 2010; Laanksonen et al., 2006; Semmler et al., 2007; Skurvydas et al., 2010) and decreased cycling performance efficiency (Horita et al., 2003; Moysi et al., 2005). Repetitive prior drop jumps (PDJ) from $0.4 \mathrm{~m}$ height induce long lasting (within 24-48 h of recovery) muscle fatigue, DOMS and increased CK activity (Skurvydas et al., 2000, 2007; Gorianovas et al., 2010).

The surface electromyography (sEMG) signal is commonly used to evaluate neuromuscular fatigue during isometric leg muscle actions (Hendrix et al., 2009) and cycling exercise (Camic et al., 2010). Fatigue is characterized by an increase in sEMG amplitude that reflects the recruitment of additional motor units, increased firing rates, and/ 
or synchronization (Basmajian, DeLuca, 1985; Hortobagy et al., 1996). It has been reported that prior heavy cycling increases integrated EMG (iEMG) of thigh muscle during heavy cycling (Burnley et al., 2002) and in contrast no alteration of the root mean square (RMS) of sEMG during moderate cycling has been observed (Gonzales, Scheuermann, 2008). Recent study results have demonstrated increases in sEMG amplitude during biceps brachii isometric contractions for at least 24 hours after eccentric exercises (Semmler et al., 2007; Starbuck, Eston, 2011). We have not found data about the residual effect of DOMS induced eccentric exercise on EMG during dynamic exercise.

The aim of the study was to asses the residual effect of 100 PDJ on the EMG of $m$. vastus lateralis (mVL) and $m$. vastus medialis (mVM) during moderate (MCE) and heavy (HCE) intensity cycling exercise.

\section{RESEARCH METHODS}

Participants. Ten healthy female students (anthropometry and physical characteristics are presented in Table) volunteered to participate in this study after giving written informed consent. The subjects were physically active but did not take part in any formal physical exercise or sport program. The experimental protocol was approved by the Lithuanian Ethics Committee of Kaunas Medical University and conducted in accordance with the Declaration of Helsinki.

Incremental cycling exercise. The first and the second ventilation thresholds $\left(\mathrm{VT}_{1}\right.$ and $\mathrm{VT}_{2}$, respectively) and peak oxygen uptake $\left(\dot{V} O_{2 \text { peak }}\right)$ were evaluated using an incremental cycling exercise (ICE) test (two W every five s) on an electronically braked cycle ergometer "Ergometrics-800S" (Ergo Line, Medical Measurement Systems; Binz, Germany) at a pedal cadence of $70 \mathrm{rpm}$. The test was started by three min of baseline pedalling at $20 \mathrm{~W}$ and continued until the intensity of cycling could not be maintained at the required level for longer than $10 \mathrm{~s}$. Subjects breathed through low resistance mouthpiece and gas exchange was measured breath-by-breath using wireless portable ergospirometric system "Oxycon mobile" (Viasys Healthcare; California, USA). The average value of $\dot{V} \mathrm{O}_{2}$ over the last $30 \mathrm{~s}$ of cycling was referred to as $\dot{V} O_{2 \text { peak }}$ and the $\mathrm{VT}_{1}$ and $\mathrm{VT}_{2}$ were determined from the result of the ICE. The seat and handlebar positions on the cycle ergometer were adjusted for each subject prior to initial exercise test and maintained in that position for the subsequent exercise tests.

Moderate and heavy cycling exercises. The intensity of MCE test was $80 \%$ of $\mathrm{VT}_{1}$ and the intensity of $\mathrm{HCE}$ test was $\triangle 50 \%$ of $\mathrm{VT}_{2}$ and $\mathrm{VT}_{1}$ values $\left(\left(\mathrm{VT}_{1}+\mathrm{VT}_{2}\right) \cdot 2^{-1}\right)$. The MCE and $\mathrm{HCE}$ were preceded by three min of baseline pedalling at $20 \mathrm{~W}$ when six min moderate / heavy cycling and three min baseline $(20 \mathrm{~W})$ pedalling at a pedal cadence of 70 r.p.m. were performed.

Prior drop jumps. Subjects performed 100 drop jumps from a $0.47 \mathrm{~m}$ stage with $20 \mathrm{~s}$ of recovery between every drop jump. After drop the subject got to amortization phase while the knee joints were flexed at the angle of 90 degrees when the subject performed a vertical jump (hands on hips).

Plasma creatine kinase activity and blood lactate concentration. Blood sample $(25 \mu \mathrm{l})$ for the measurement of blood lactate concentration ([La]) (Accutrend Portable Lactate Analyzer, Roche, Germany) was taken from fingertips.

Approximately $2500 \mu \mathrm{l}$ of capillary blood sample was collected into a tube containing lithium heparin to determine the $\mathrm{CK}\left(\mathrm{IU} \cdot \mathrm{L}^{-1}\right)$ activity by using an automatic biochemical analyzer "Spotchem EZ SP-4430" (Arkray Inc, Kyoto, Japan).

Muscle soreness and perceived exertion rating. DOMS was reported subjectively performing one squat using a visual scale of $0-10$ points in which 0 represented no pain and 10 represented intolerably intense pain.

The subject was asked to rate their perceived exertion (RPE) using the Borg scale, ranging from 6 to 20 (7 - very, very light; 19 - very, very heavy).

EMG recording. Bipolar $\mathrm{Ag}-\mathrm{AgCl}$ surface electrodes were used for sEMG recordings (silver

\begin{tabular}{l|l|l|c|c|c|c|c|c|c|}
$\begin{array}{l}\text { Table. Subjects' descriptive } \\
\text { characteristics. Values are } \\
\text { means (SD) }\end{array}$ & $\begin{array}{c}\text { Subjects } \\
(\mathbf{n = 1 0})\end{array}$ & $\begin{array}{c}\text { Age, } \\
\mathbf{y r s}\end{array}$ & $\begin{array}{c}\text { Weight, } \\
\mathbf{~ k g}\end{array}$ & Height, m & $\begin{array}{c}\text { Body fat, } \\
\mathbf{\%}\end{array}$ & $\begin{array}{c}\text { Free fat } \\
\text { mass, } \mathbf{~ k g}\end{array}$ & $\begin{array}{c}\text { Maximal } \\
\text { power, W }\end{array}$ & $\begin{array}{c}\text { VO } \\
\mathbf{m l} / \mathbf{k g} / \mathbf{m i n}\end{array}$ \\
\cline { 2 - 11 } $\begin{array}{l}\text { Note. } \mathrm{VO}_{2 \text { peak }} \\
\text { oxygen uptake. }\end{array}$ & Melative peak & 21.5 & 60.8 & 1.70 & 25.9 & 44.9 & 198 & 36.48 \\
$(1.9)$ & $(4.5)$ & $(0.06)$ & $(3.8)$ & $(2.3)$ & $(20)$ & $(5.00)$ \\
\hline
\end{tabular}


bar electrodes, diameter $10 \mathrm{~mm}$, centre-to-centre distance $20 \mathrm{~mm}$ ) of the long head of the right leg $\mathrm{mVL}$ and mVM (DataLog type No. P3X8 USB, Biometrics Ltd, Gwent, UK). The skin at the electrode site was shaved and cleaned with alcohol wipes. To be sure, that electrode was precisely at the same place for each testing session, the electrode location was marked on the skin with an indelible marker. The electrodes were placed $2 \cdot 3^{-1}$ on $\mathrm{mVL}$ and $80 \%$ way on $\mathrm{mVM}$ of line between ischial tuberosity and fibula head. The ground electrode was positioned on the wrist of right hand. The RMS of sEMG values were calculated during 10 last seconds of every MCE and HCE minutes. The RMS of sEMG results are represented as group means response.

Experimental protocol. Subjects reported to the laboratory on four separate days within a twothree week period. Exercise testing was performed at approximately the same time of day for each subject. The first session was used to familiarize subjects with the testing equipment and procedures. In the same session, each subject performed an ICE test (after five min warm up and five min rest). Subsequently, in the second session (no less then 48 hours rest after ICE) subject performed control (CON) MCE and after five minutes rest HCE. On the third occasion subject performed PDJ and after 45 minutes (45'PDJ) they performed the same MCE and HCE. On the forth occasion subject performed MCE and HCE 24 hour after PDJ (24h PDJ). The [La] was taken at five min and $20 \mathrm{~min}$ after ICE test and at the end of MCE and HCE tests. At the end of MCE and HCE, each subject was asked to rate her perceived exertion. CK activity in was measured and DOMS was rated $24 \mathrm{~h}$ after PDJ.

Statistical analysis. RMS of sEMG, [La] and RPE were analyzed using two-way repeated measures ANOVA design evaluating time and testing conditions (CON; 45' PDJ; 24h PDJ) as the main effects. Significant results were further analyzed using Turkey HDS post hoc test. Statistical significance was accepted when $\mathrm{p}<0.05$. All data are reported as the mean (SE).

\section{RESEARCH RESULTS}

The power output of MCE and HCE was 82 (16) $\mathrm{W}$ and 130 (17) W, respectively, which corresponds to 40.8 (5.1) and $66.6(4.5) \%$ of maximal power.

The RMS of mVL (Figure 1) significantly increased $24 \mathrm{~h}$ PDJ compared with CON ( $\mathrm{p}=0.03)$ during MCE with no changes in mVM (Figure 2). No significant differences in RMS of mVL (Figure 3) and $\mathrm{mVM}$ (Figure 4) were observed during HCE between CON, 45'PDJ and 24h PDJ, but RMS of $\mathrm{mVL}$ statistically increased minute 5 compared with minute $1(\mathrm{p}=0.02)$ and minute $2(\mathrm{p}=0.03)$ under CON (Figure 2). There were significant differences of RMS of mVL between minute 1 and minute $4(\mathrm{p}=0.02)$ under $45^{\prime}$ PDJ, and minute 5 compared with minute $1(\mathrm{p}=0.02)$ and minute 2 $(\mathrm{p}=0.03)$ under $24 \mathrm{~h}$ PDJ condition.

The [La] did not differ 45'PDJ (3.61 (0.94) $\mathrm{mmol} / \mathrm{L}$ ) and 24h PDJ (3. $48(0.66) \mathrm{mmol} / \mathrm{L}$ ) compared with CON $(3.43(0.92) \mathrm{mmol} / \mathrm{L})$ at the end of MCE. There was no significant difference in [La] at the end of HCE between different testing

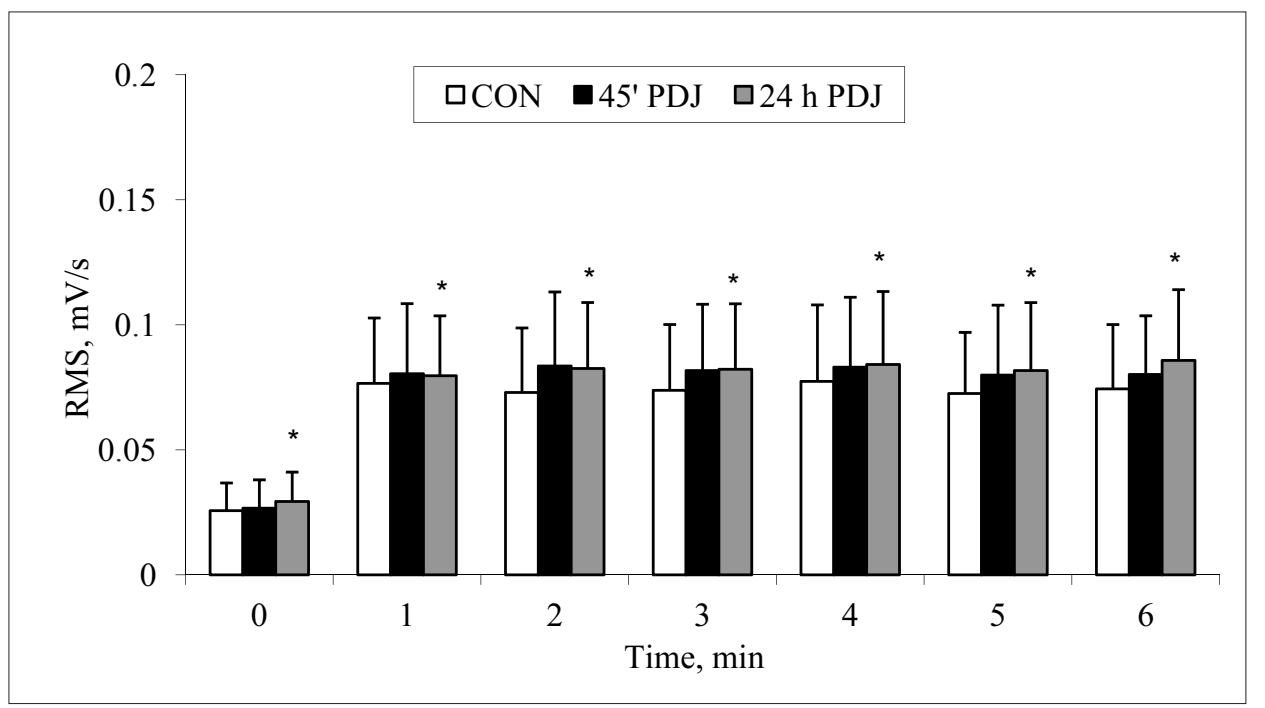

Figure 1. Group mean response of $m$. vastus lateralis in RMS of sEMG during moderate cycling exercise under control condition (CON); 45 minutes after prior drop jumps (45'PDJ) and 24 hours after prior drop jumps (24 h PDJ)
Note. 0 represents base line (20 W) cycling. *-significant difference between $24 \mathrm{~h}$ PDJ and $\mathrm{CON}$. 
Figure 2. Group mean response of $m$. vastus medialis in RMS of sEMG during moderate cycling exercise under control condition (CON); 45 minutes after prior drop jumps (45'PDJ) and 24 hours after prior drop jumps (24 h PDJ)

Note. 0 represents base line $(20 \mathrm{~W})$ cycling.

Figure 3. Group mean response of $\boldsymbol{m}$. vastus lateralis in RMS of sEMG during heavy cycling exercise under control condition (CON); 45 minutes after prior drop jumps (45'PDJ) and 24 hours after prior drop jumps (24 h PDJ)

Note. 0 represents base line (20 W) cyc-ling. \# - significant differences from $1 \mathrm{~min}$; significant differences from $2 \mathrm{~min}$.

Figure 4. Group mean response of $\boldsymbol{m}$. vastus medialis in RMS of SEMG during heavy cycling exercise under control condition (CON); 45 minutes after prior drop jumps (45'PDJ) and 24 hours after prior drop jumps (24 h PDJ)

Note. 0 represents base line $(20 \mathrm{~W})$ cycling.
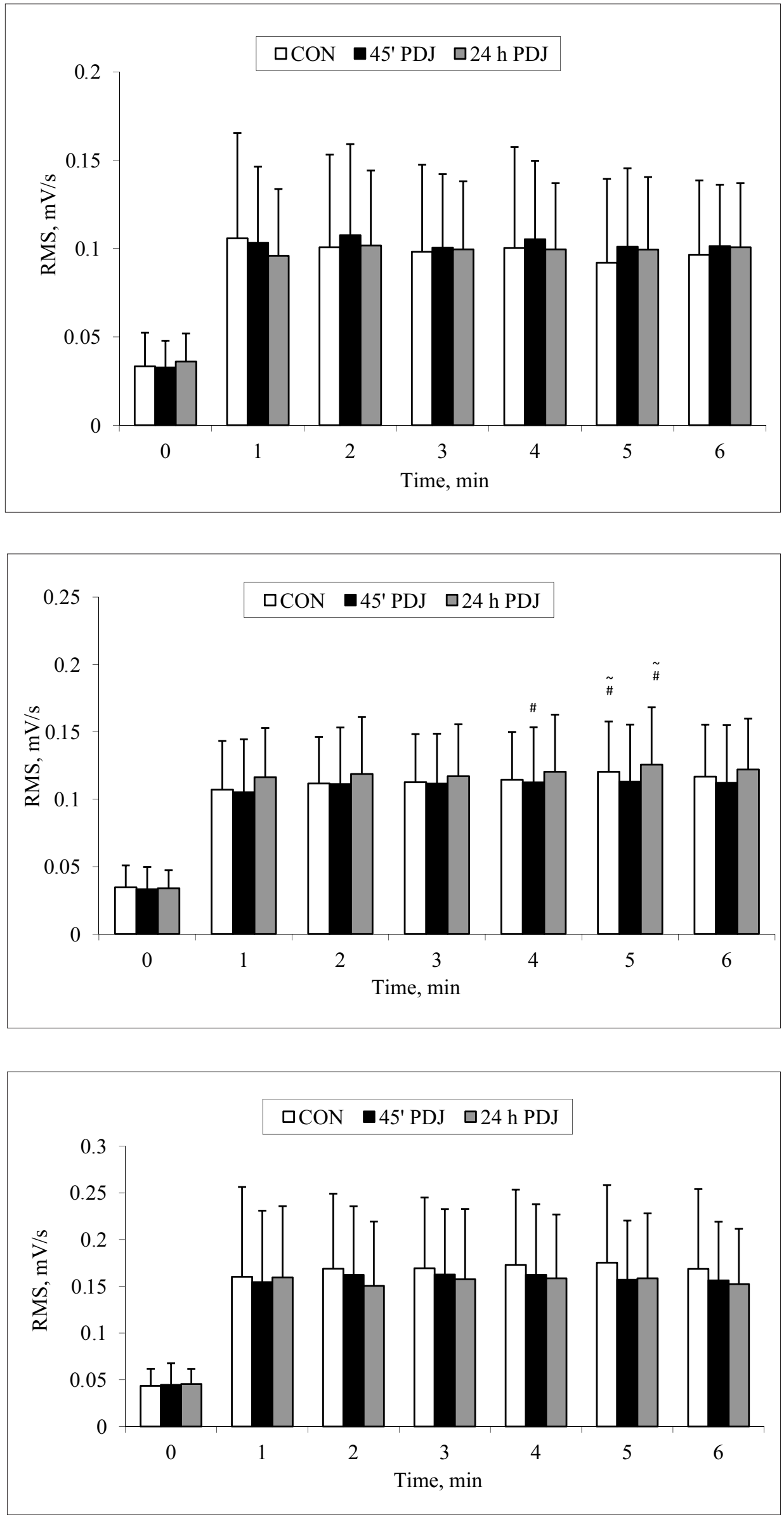
conditions (CON - 7.25 (2.06); 45' PDJ - 7.05 (2.46); $24 \mathrm{~h}$ PDJ - 7.58 (2.55)). The CK activity was 308.1 (283.0) IU/L 24 hours after PDJ.

The ratings of perceived exertion during MCE (CON - 11.6 (1.4); 45'PDJ - 11.9 (1.5); $24 \mathrm{~h}$ PDJ - 11.6 (1.3)) and HCE (CON - 14.8 (1.4); 45' PDJ - 15.7 (1.81); 24 h PDJ - 15.7 (2.2) did not differ between testing conditions. The mean values of DOMS was 5.09 (2.59) points of 10 point scale.

\section{DISCUSSION}

The mVM and mVL has been commonly studied as most active muscles during cycling exercises (Burnley et al., 2002; Gonzales, Scheuermann, 2008; Hug, Dorel, 2009). In the present study the RMS of sEMG increased of $\mathrm{mVL}$ $24 \mathrm{~h}$ after PDJ induced moderate DOMS with no alteration of $\mathrm{mVM}$ during MCE. The moderate DOMS confirms muscle damage in the present study sustaining a strong relationship between muscle soreness within 24-48 h after thigh muscle stretch shortening exercises and decrease in neuromuscular performance (Skurvydas et al., 2007). The increases in sEMG amplitude during isometric contractions of biceps brachii after eccentric exercises (Semller et al., 2007) suggest that the muscle damage from eccentric exercise produces changes in the central nervous system that act to increase motor unit activity during voluntary contractions for at least 24 hours. However, in the present study muscle damage was induced on thigh muscles and there is evidence that the arm muscles are equally more susceptible to muscle damage than leg muscles associated with the use of muscles in daily activities (Chen et al., 2011). Anyway, despite of work load and muscle group differences, the residual effect of eccentric exercise is similar. The rise of sEMG amplitude during fatiguing constant-load exercise could be mainly attributed to progressive recruitment of additional motor units, as fatigue occurs and there is assumption that fatigue induces changes of the coordination of the lower limb muscles (Hug, Dorel, 2009). In addition, after heavy exercise the increase in iEMG early in the second heavy exercise represents additional motor units' recruitment and fatigued fibres may be activated, but they may fail to produce any tension, resulting in the need to recruit more muscle fibres to maintain the power output (Hughson et al., 2000). Moreover, the increase in motor units' recruitment for the same power output could reduce the work efficiency (Burnley et al., 2002). Nevertheless, the RMS of sEMG reflects overall motor unit recruitment and does not provide information regarding the type of motor units contributing to the measured myoelectrical signal (Gonzales, Scheuermann, 2008). However, all muscle fibres showed a shift length - tension relation, indicative of damage, but type I fibres showed a smaller shift then type II fibres after a series of eccentric contractions (Proske, Morgan, 2001). Therefore, it is possible to suppose that increased RMS of sEMG $24 \mathrm{~h}$ PDJ has been effected by additional type I fibres recruitment of $m$. $V L$ during MCE in the present study because of deficits in force measured at two hours or later after the eccentric contractions are likely to be only caused by the damage (Proske, Allen, 2005).

The increases of RMS of $m$. VL at the fifth minute of the HCE compared with exercise beggining (1 and 2 minutes) both $\mathrm{CON}$ and fatigue conditions in the present study possibly could be explained by the fact that composition of muscle fibres type that make up the RMS signal may change following heavy exercise as type I fibres are progressively replaced by type II fibres in the presence of muscle fatigue during cycling (Gonzales, Scheuermann, 2008). The unaltered RMS of sEMG during HCE after PDJ could be explained by preceding MCE, which dominant mode was eccentric ant this supposition confirms resent finding suggesting that the eccentric training of thigh muscle resulted in a switch to oxidative metabolism, which may be associated with protection from DOMS (Hody et al., 2011). Moreover, the RMS of mVM has been unaffected by PDJ during both MCE and HCE in the present study, and possibly could be explained by different muscle feedback on PDJ.

In the present study participants rated their perceived exertion as "moderate" during MCE and "heavy", but PDJ seems to have no residual effect on RPE. In addition, the unaltered [La] during MCE and HCE demonstrate similar ATP glycolysis under different testing (CON; 45'PDJ and $24 \mathrm{~h}$ PDJ) conditions.

\section{CONCLUSIONS AND PERSPECTIVES}

In conclusion, prior drop jumps seem to have significant residual (within $24 \mathrm{~h}$ of recovery) effect on RMS of sEMG of $m$. vastus lateralis during moderate cycling exercise without any causes during heavy cycling exercise in female students. The $m$. vastus lateralis possibly is more vulnerable than $m$. vastus medialis to prior eccentric concentric exercise. 


\section{REFERENCES}

Basmajian, J. V., DeLuca, C. J. (1985). Muscles Alive: Their Functions Revealed by Electromyography. Baltimore: Williams \& Wilkins.

Burnley, M., Doust, J. H., Ball D., Jones, A. M. (2002). Effects of prior heavy exercise on $\mathrm{VO}_{2}$ kinetics during heavy exercise are related to changes in muscle activity. Journal of Applied Physiology, 93, 167-174.

Camic, C. L., Housh, T. J, Johnson, G. O. et al. (2010). An EMG frequency-based test for estimating the neuromuscular fatigue threshold during cycle ergometry. European Journal of Applied Physiology, 108, 337-345.

Chen, T. C., Lin, K. Y., Chen, H. L., Lin, M. J., Nosaka, K. (2010). Comparison in eccentric exerciseinduced muscle damage among four limb muscles. European Journal of Applied Physiology, 111, 211-223.

Dartnall, T. J., Rogasch, N. C., Nordstrom, M. A., Semmler, J. G. (2009). Eccentric muscle damage has variable effects on motor unit recruitment thresholds and discharge patterns in elbow flexor muscles. Journal of Neurophysiology, 102 (1), 413-423.

Gleeson, M., Blannin, A. K., Zhu, B., Brooks, S., Cave, R. (1995). Cardiorespiratory, hormonal and haematological responses to submaximal cycling performed 2 days after eccentric or concentric exercise bouts. Journal of Sport and Exercise, 6, 471-479.

Gonzales, J. U., Scheuermann, B. W. (2008). Prior heavy exercise increases oxygen cost during moderate exercise without associated change in surface EMG. Journal of Electromyography and Kinesiology, 18, 99-107.

Gorianovas. G., Streckis, V., Skurvydas, A. et al. (2010). Does the repeated bout effect of exercise evoke similar changes in the motor system of men and women? Ugdymas. Kūno kultūra. Sportas, 1 (76), 32-38.

Hendrix, C. R., Housh, T. J., Johnson, G. O. et al. (2009). A new EMG frequency-based fatigue threshold test. Journal of Neuroscience Methods. 181, 45-51.

Hody, S., Leprince, P., Sergeant, K. et al. (2011). Human muscle proteome modifications after acute or repeated eccentric exercises. Medicine and Science in Sports Exercise, 43 (12), 2281-2296.

Horita, T., Komi, V., Hamalainen, I., Avela, J. (2003). Exhausting stretch-shortening cycle (SSC) exercise causes greater impairment in SSC performance than in pure concentric performance. European Journal of Applied Physiology, 88, 527-534.

Hortobagyi, T., Hill, J. P., Houmard, J. A. et al. (1996). Adaptive responses to muscle lengthening and shortening in humans. Journal of Applied Physiology, 80, 765-772.

Hug, F., Dorel, S. (2009). Electromyographic analysis of pedaling: A review. Journal of Electromyography and Kinesiology, 19, 182-198.
Hughson, R. L., O’Leary, D. D., Betik, A. C., Hebestreit, H. (2000). Kinetics of oxygen uptake at the onset of exercise near or above peak oxygen uptake. Journal of Applied Physiology, 88, 1812-1819.

Laaksonen, M. S., Kivelä, R., Kyröläinen, H. et al. (2006). Effects of exhaustive stretch-shortening cycle exercise on muscle blood flow during exercise. Acta Physiologica (Oxford), 186 (4), 261-270.

Malm, C., Yu, J. G. (2012). Exercise-induced muscle damage and inflammation: Re-evaluation by proteomics. Histochemestry and Cell Biology, Apr 10 [Epub].

Moysi, J. S., Garcia-Romero, J. C., Alvero-Cruz, J. R. et al. (2005). Effects of eccentric exercise on cycling efficiency. Canadian Journal of Applied Physiology, 30, 259-275.

Proske, U., Allen, T. J. (2005). Damage to skeletal muscle from eccentric exercise. Exercise and Sport Science Review, 2, 98-104.

Proske, U., Morgan., D. L. (2001). Muscle damage from eccentric exercise: Mechanism, mechanical signs, adaptation and clinical applications. Journal of Physiology, 535, 98-104.

Semmler, J. G., Tucker, K. J., Allen, T. J. (2007). Eccentric exercise increases EMG amplitude and force fluctuations during submaximal contractions of elbow flexor muscles. Journal of Applied Physiology, 103, 979-989.

Skurvydas, A., Brazaitis, M., Kamandulis, S. (2010). Prolonged muscle damage depends on force variability. International Journal of Sport and Medicine, 31, 77-81.

Skurvydas, A., Jascaninas, J., Zachovajevas, P. (2000). Changes in height of jump, maximal voluntary contraction force and low-frequency fatigue after 100 intermittent or continuous jumps with maximal intensity. Acta Physiologica Scandinavica, 169, 55-62.

Skurvydas, A., Mamkus, G., Dudoniene, V. et al. (2007). The time-course of voluntary and electrically evoked muscle performance during and after stretch-shortening exercise is different. Journal of Sports Science and Medicine, 6, 408-416.

Starbuck, C., Eston, R. G. (2012). Exercise-induced muscle damage and the repeated bout effect: evidence for cross transfer. European Journal of Applied Physiology, 112, 1005-1013.

Stupka, N., Lowther, S., Chorneyko, K. et al. (2000). Gender differences in muscle inflammation after eccentric exercise. Journal of Applied Physiology 89, 2325-2332.

Stupka, N., Tarnopolsky, M. A., Yardley, N. J., Phillips, S. M. (2001). Cellular adaptation to repeated eccentric exercise-induced muscle damage. Journal of Applied Physiology, 91,1669-1678. 


\title{
ŠUOLIŲ PRIEŠKRŪVIO POVEIKIS ŠLAUNIES RAUMENŲ EMG RODIKLIAMS ATLIEKANT VIDUTINIO IR DIDELIO INTENSYVUMO KRŪVIUS VELOERGOMETRU
}

\author{
Neringa Baranauskienė, Loreta Stasiulè, Sandra Raubaitė, Arvydas Stasiulis \\ Lietuvos kūno kultūros akademija, Kaunas, Lietuva
}

\begin{abstract}
SANTRAUKA
Tyrimo pagrindimas ir hipotezė. Ekscentriniai-koncentriniai pratimai sukelia ilgai trunkantị raumenų nuovargị ir vèluojantį raumenų skausmą. Be to, esant nuovargiui, raumenų elektrinis aktyvumas padidejja krūvio metu. Manoma, kad atliekant pastovaus intensyvumo krūvius veloergometru po ekscentrinių pratimų, sukeliančiu vèluojantị raumenų skausmą, šlaunies raumenų elektrinis aktyvmas padideja.

Tikslas - nustatyti 100 nušokimų vertikaliu šuoliu (NVŠ) poveiki šlaunies raumenų elektromiogramos pokyčiams atliekant vidutinio ir didelio intensyvumo krūvius veloergometru.

Metodai. Skirtingų testavimų metu 10 merginų atliko vieną nuosekliai didinamą krūvi, per kitus tris kartus (kontrolini testavimą praejus 45 minutems ir 24 valandoms po NVŠ) tiriamosios atliko vidutinio ir didelio intensyvumo krūvius veloergometru („,Ergotine-800“, Vokietija). Mynimo dažnumas -70 k./min. Vidutinio ir didelio krūvio metu buvo registruojamas dešinès kojos šlaunies išorinio ir vidinio raumens EMG. Praëjus 24 valandoms po NVŠ, tiriamosios vertino skausmą ir buvo nustatomas kreatinkinazės aktyvumas kraujyje.

Rezultatai. Tiriamosios jautè vidutini šlaunies raumenų skausmą praejus 24 valandoms po NVŠ $(5,0(2,79)$ balo). Atliekant VK išorinio šlaunies raumens EMG amplitudès vidutinė kvadratinè reikšmė padidèjo praejus 24 valandoms po NVŠ, tačiau DK metu šlaunies raumenų EMG reikšmingai nepakito.

Aptarimas ir išvados. Apibendrinant galima teigti, kad 100 nušokimų vertikaliu šuoliu, praëjus 24 valandoms po jų, padidina šlaunies raumenų EMG amplitudę vidutinio intensyvumo krūvio metu.
\end{abstract}

Raktažodžiai: vèluojantis raumenų skausmas, pastovus krūvis, EMG amplitudès vidutinè kvadratinè reikšmè. 